\title{
Article \\ Features of Metabolic Support of Physical Performance in Highly Trained Cross-Country Skiers of Different Qualifications during Physical Activity at Maximum Load
}

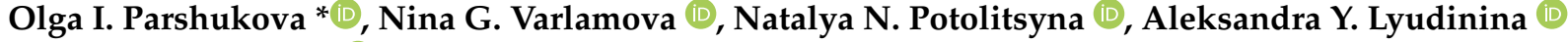 \\ and Evgeny R. Bojko (D)
}

check for

updates

Citation: Parshukova, O.I.;

Varlamova, N.G.; Potolitsyna, N.N.; Lyudinina, A.Y.; Bojko, E.R. Features of Metabolic Support of Physical Performance in Highly Trained Cross-Country Skiers of Different Qualifications during Physical Activity at Maximum Load. Cells 2022, 11, 39. https://doi.org/ $10.3390 /$ cells11010039

Academic Editor: Robert Wessells

Received: 1 December 2021

Accepted: 21 December 2021

Published: 23 December 2021

Publisher's Note: MDPI stays neutral with regard to jurisdictional claims in published maps and institutional affiliations.

Copyright: (C) 2021 by the authors. Licensee MDPI, Basel, Switzerland. This article is an open access article distributed under the terms and conditions of the Creative Commons Attribution (CC BY) license (https:// creativecommons.org/licenses/by/ $4.0 /)$.
Institute of Physiology of Komi Science Centre of the Ural Branch of the Russian Academy of Sciences, FRC Komi SC UB RAS, 50 Pervomayskaya Str., 167982 Syktyvkar, Russia; nivarlam@physiol.komisc.ru (N.G.V.); potol_nata@list.ru (N.N.P.); salu_06@inbox.ru (A.Y.L.); boiko60@inbox.ru (E.R.B.)

* Correspondence: olga-parshukova@mail.ru

\begin{abstract}
The purpose of our study was to identify the features of metabolic regulation in highly trained cross-country skiers of different qualifications at different stages of the maximum load test. We examined 124 highly trained cross-country skiers (male, ages 17-24). The group consisted of two subgroups based on their competition performance: 61 nonelite athletes (Group I) and 63 elite athletes (group II), who were current members of the national team of the Komi Republic and Russia. The bicycle ergometer test was performed by using the OxyconPro system (Erich Jaeger, Hoechberg, Germany). All the examined athletes performed the exercise test on a cycle ergometer "until exhaustion". The results of our research indicate that the studied groups of athletes with high, but different levels of sports qualifications are a convenient model for studying the molecular mechanisms of adaptation to physical loads of maximum intensity. Athletes of higher qualifications reveal additional adaptive mechanisms of metabolic regulation, which is manifested in the independence of serum lactate indicators under conditions of submaximal and maximum power from maximal oxygen uptake, and they have an NO-dependent mechanism for regulating lactate levels during aerobic exercise, including work at the anaerobic threshold.
\end{abstract}

Keywords: nitric oxide; lactate; heart rate; oxygen uptake; arterial blood pressure; exercise test on a cycle ergometer; cross-country skier

\section{Introduction}

Moderate physical activity has a positive effect on the morphology and work of the cardiovascular system of athletes due to the manifested adaptive response of the myocardium [1]. However, at the same time, a violation in the consistency of the functional state of the system associated with the work of the heart rhythm leads to an overstrain of the cardiovascular system of athletes [2]. Systematically exercising athletes usually develop myocardial hypertrophy. Pathological hypertrophy is based on dystrophic changes in the myocardium and deterioration of the microvasculature, which leads to difficulty in contraction of the left ventricular wall, which ultimately affects the decrease in the athletic performance of the body [3]. Cross-country skiers have a very high maximal oxygen uptake, and they are able to perform submaximal exercise at a rather high metabolic rate, and with cardiac output levels similar to or higher than the cardiac output levels achieved by untrained humans at maximal exercise [4]. The role of the molecular gas nitric oxide (NO) in the cardiovascular system is well established, where NO regulates a multitude of cellular processes. Endothelial cells synthesize and release NO, which mediates diverse effects, including vessel tone, haemostasis, blood pressure and vasculature remodelling [5]. The significance of $\mathrm{NO}$ for cardiomyocyte function is well known because it plays a role in the regulation of ion channels, $\mathrm{Ca} 2$ homeostasis, contractility, energetics, cell growth, and it has antioxidant effects and prevents endothelial cells from oxidative stress [6]. 
The "gold standard" of cardiorespiratory exercise testing - a test with increasing load-allows you to determine the maximum oxygen uptake, assess the level of aerobic capacity of the body and identify the reasons for limiting physical performance [7]. Currently, there are many protocols for exercise testing. However, at different stages of the test, there is practically no information about the functional parameters of the cardiorespiratory system and human biochemical markers, such as heart rate, blood pressure, QRS complex, QT interval, oxygen uptake, carbon dioxide production, respiratory rate and the levels of stable nitric oxide metabolites (nitrites, nitrates) and lactate. This significantly complicates the analysis, comparison and prediction of available data. The purpose of our study was to identify the features of metabolic regulation in highly trained cross-country skiers of different qualifications at different stages of testing at physical maximum load.

\section{Materials and Methods}

\subsection{Ethical Approval}

The Ethics Committee of the Institute of Physiology of the Russian Academy of Sciences, Syktyvkar approved the experimental design and protocol of the study. The study conformed to the Code of Ethics of the World Medical Association (Declaration of Helsinki). The volunteers were made aware of all the information about the experimental protocol, experimental procedures, and probable risks and inconvenience associated with performing the exercise test on a cycle ergometer "until exhaustion". After the necessary interpretations, the volunteers gave their written informed agreement to participate in the test. Participants were aware that they were free to leave the study at any time and without consequence.

\subsection{Participants}

The observation group included 124 highly trained cross-country skiers (male, ages 17-24). The group consisted of two subgroups based on their competition performance: Group I includes 61 nonelite athletes who occupied the last ten places at official competitions, and Group II includes 63 elite athletes who occupied the first ten places at official competitions, who were current members of the national team of the Komi Republic and Russia, had no signs or history of chronic diseases. All participants had more than 5 years of cross-country skiing practice as part of their main training schedule and had extensive experience in endurance events.

\subsection{Experimental Protocol}

The study was performed during the morning after a low-nitrate breakfast. It excluded foods and drinks that are the main sources of nitrates in human food (meat and fish products, vegetables (mainly beets, leafy green vegetables), marinades, (spirits, fruit and mineral drinks). Additionally, the night before the test all the participants consumed a standardized meal $(1,674,400-1,757,420 \mathrm{kJcal})$ consisting of (in units of the percentage of the total energy supplied by the entire meal, En\%) 78 En\% carbohydrate, 14 En\% fat and $8 \mathrm{En} \%$ protein. The dietary intake of the participants was assessed using a food frequency questionnaire. Calories consumed at breakfast were not standardize by body weight. The height and body weight of the athletes were measured using a medical weight growth meter (Accunig, SELVAS Healthcare, Daejeon, Korea). At rest (sitting), at the anaerobic threshold (AT) level, during peak load and during the recovery period (5th minute) in each of the athletes examined were determined by the following parameters: systolic blood pressure (SBP), diastolic pressure (DBP), heart rate (HR), $Q$ wave, $R$ wave, and $S$ wave (QRS) complex, QT interval (QT), oxygen uptake $\left(\mathrm{V}^{\prime} \mathrm{O}_{2}\right)$, carbon dioxide production $\left(\mathrm{V}^{\prime} \mathrm{CO}_{2}\right)$, respiratory rate (Rer), and the levels of stable metabolites of $\mathrm{NO}$ and lactate in capillary blood samples. Blood pressure was measured by the Korotkov method on the right arm using the Microlife model BRAG-1-30 device (Widnau, Switzerland). An electrocardiogram (ECG) was recorded in 12 leads: standard according to Einthoven (I, II, III), reinforced from the extremities according to Goldberger (aVR, aVL, aVF), and thoracic according to Wilson (V1-6). Manual measurements of ECG characteristics were performed using a ruler for 
measuring and evaluating electrocardiograms from "Heinrich Mack Nachf" (Karlsruhe, Germany). Heart rate, oxygen uptake, carbon dioxide production, and respiratory rates were obtained from test protocols.

\subsection{Exercise Test on a Cycle Ergometer "until Exhaustion"}

On an ergometer bike ("Ergose-lect-100", Ergoline GmbH, Hoechberg, Germany) was performed aerobic capacity $\left(\mathrm{V}^{\prime} \mathrm{O}_{2}\right.$ max) testing in the "breath by breath" mode. The parameters were averaged over 15-s segments. The test included one minute of cycling without load (for adaptation of participants) followed by stepwise load increases of $40 \mathrm{~W}$ in 2 min increments. The first load started from $120 \mathrm{~W}$. During the test, the pedalling speed was $60 \mathrm{rpm}$. The anaerobic threshold (AT) was determined by reaching a respiratory coefficient of $1[8,9]$.

\subsection{Determination of $\mathrm{NO}_{x}$}

The NO levels in the plasma were measured using the Griess reaction, by evaluating the stable metabolites of $\mathrm{NO}$, including nitrites $\left.\left(\mathrm{NO}_{2}\right)(-)\right)$ and nitrates $\left.\left(\mathrm{NO}_{3}\right)(-)\right)$, which were pre-sorted as an index [ $\left.\mathrm{NO}_{\mathrm{x}}\right]$. As described earlier in our article [5], nitrite and nitrate are the terminal products of $\mathrm{NO}$ in human plasma. It is known that a strong correlation between endogenous $\mathrm{NO}$ production and $\mathrm{NO}_{\mathrm{x}}$ levels exist in plasma [10]. Blood samples with a volume of two $\mathrm{ml}$ were collected into tubes with heparin and centrifuged for $20 \mathrm{~min}$ at $2500 \times \mathrm{g}$. The separated plasma was stored at $-40{ }^{\circ} \mathrm{C}$ until analysis. After deproteinization of plasma samples by precipitation in ethanol and centrifugation, the supernatants were incubated for $30 \mathrm{~min}$ at $37^{\circ} \mathrm{C}$ with vanadium chloride to convert nitrate to nitrite. Next, the samples were mixed with Griess reagent. Samples were measured at a wavelength of $540 \mathrm{~nm}$ using a Spectronic Genesys-6 Spectrophotometer (Thermo Electron Scientific Instruments LLC, Madison, WI, USA). Total nitrite was measured using the Griess reagent. Samples were measured twice against a standard nitrite curve with a known concentration. The plasma nitrate concentration was calculated by subtracting the primary nitrite concentration from the total nitrite concentration. All chemicals used for NO determination were obtained from Sigma (St. Louis, MO, USA). The detection limit for $\mathrm{NO}$ was $0.001 \mu \mathrm{mol} / \mathrm{L}$. The $\mathrm{NO}_{3} / \mathrm{NO}_{2}$ index was calculated as the ratio between $\mathrm{NO}_{3}$ and $\mathrm{NO}_{2}$.

\subsection{Determination of Lactate}

Plasma lactate levels were measured using a lactate pulmonary alveolar proteinosis (PAP) enzymatic colorimetric method with "Chronolab" commercial kits (Chronolab Systems, S.L. Barcelona, Spain) with an intra-assay coefficient of variance (CV) of $8 \%$. Measurements were performed using a spectrophotometer at a wavelength of $546 \mathrm{~nm}$.

\subsection{Statistical Analysis}

Statistica software (STA862D175437Q, version 6.0, StatSoft Inc., 2001, Tulsa, OK, USA) was used for statistical analysis. The mean (Me) and standard deviation (SD) were calculated. Differences in the dynamics of each parameter were tested by Friedman's ANOVA. The Wilcoxon test was used to define the correlation coefficients between two variables. The Spearman rank analysis determined the correlation coefficients between two variables. A value of $p<0.05$ was accepted as statistically significant.

\section{Results}

The characteristics of the examined groups of athletes are presented in Table 1.

The groups of the examined athletes did not have significant differences in age, weight or height (Table 1). At the same time, load power on the anaerobic threshold and maximal load power increased significantly $(p<0.05)$ with an increase in sports activity (Figure 1 ). 
Table 1. Characteristics of the subjects by group, $\mathrm{ME} \pm \mathrm{SD}$.

\begin{tabular}{ccc}
\hline Parameters & Group I $(\boldsymbol{n}=\mathbf{6 1})$ & Group II $(\boldsymbol{n}=\mathbf{6 3})$ \\
\hline AGE, YEARS & $19.1 \pm 2.1$ & $21.0 \pm 3.1$ \\
WEIGHT, KG & $69.1 \pm 4.8$ & $71.1 \pm 4.6$ \\
HEIGHT, CM & $174.9 \pm 4.7$ & $175.4 \pm 4.9$ \\
\hline
\end{tabular}

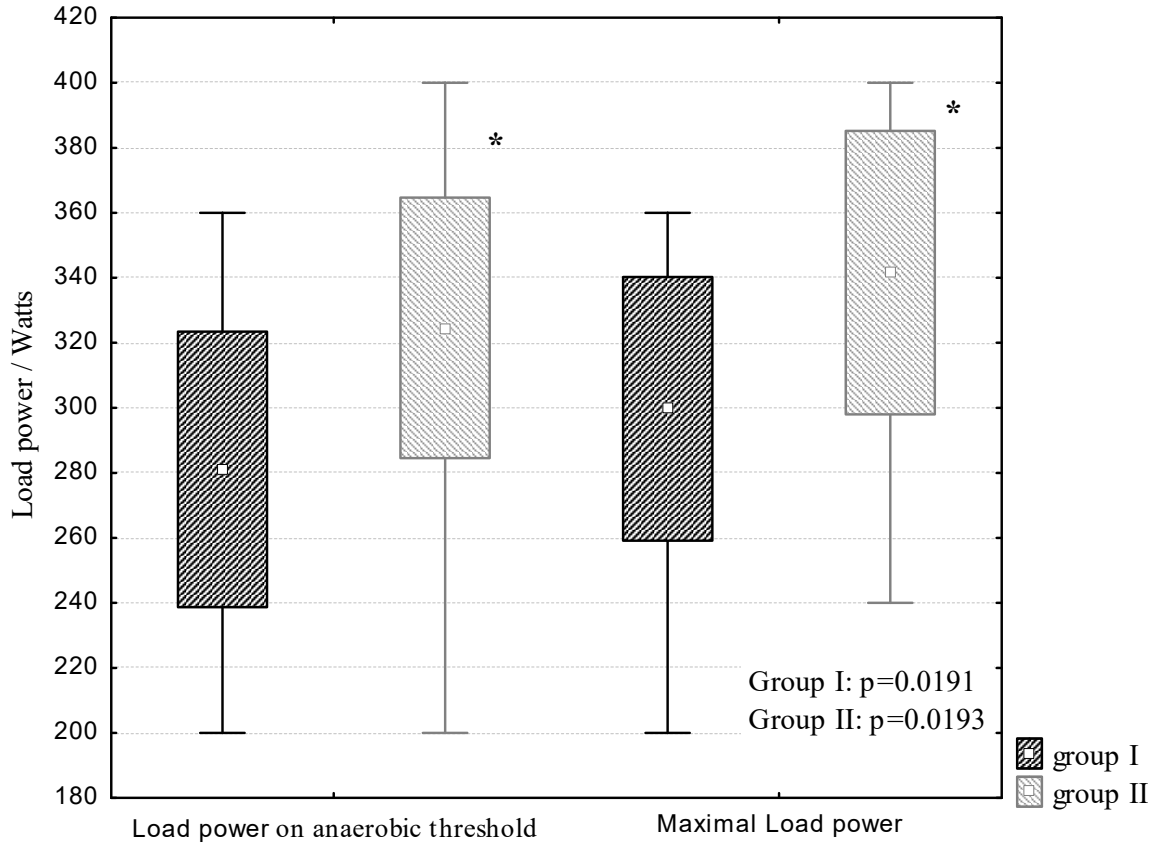

Figure 1. Load power in cross-country skiers during the exercise test on a cycle ergometer "until exhaustion" (Mean; Box: Mean \pm 2 SD; Whisker: Min-Max). ${ }^{*} p<0.05$.

When performing the test "until exhaustion", all cross-country skiers showed a statistically significant increase in oxygen uptake during the passage of the anaerobic threshold $(p=0.001)$ compared with indicators at rest (Figure 2). At the level of the AT and peak load, group II was characterized by higher values of oxygen uptake $(p<0.01$ and $p<0.001$, respectively). During the recovery period, oxygen uptake values decreased significantly in both groups $(p<0.001)$. During rest and during the recovery period, the oxygen uptake did not differ significantly in the study groups.

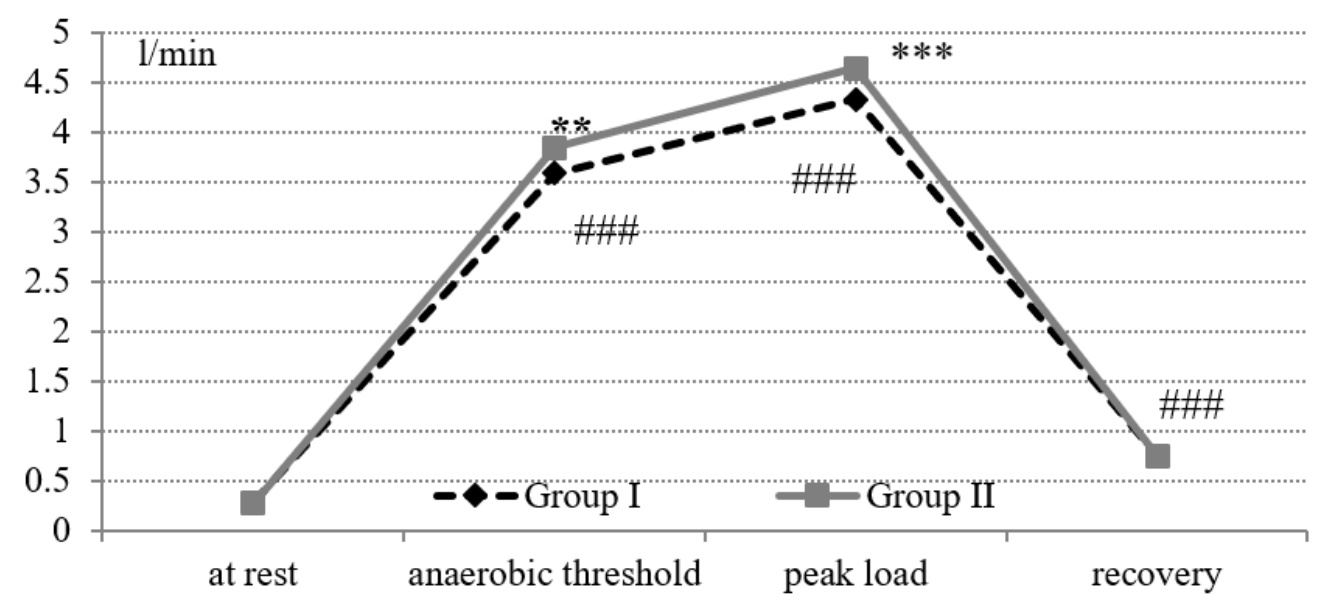

Figure 2. Oxygen uptake during the exercise test on a cycle ergometer "until exhaustion" in crosscountry skiers. Statistical significance levels between groups: ${ }^{* *} p<0.01$; ${ }^{* * *} p<0.001$. Statistical significance levels between stages of the load: \#\#\# $p<0.001$. 


\subsection{Cardiorespiratory Parameters}

All cross-country skiers showed some similar dynamics of SBP during the test "until exhaustion": an increase at AT and at peak load and a decrease at recovery $(p<0.001)$ (Table 2). At rest, Group I was characterized by higher SBP than Group II $(p<0.05)$.

Table 2. Cardiorespiratory parameters at different stages of the load in cross-country skiers, Me \pm SD.

\begin{tabular}{|c|c|c|c|c|c|}
\hline \multirow[b]{2}{*}{ Parameters } & & \multicolumn{4}{|c|}{ Stages of the Load } \\
\hline & & At Rest & $\begin{array}{l}\text { Anaerobic } \\
\text { Threshold }\end{array}$ & Peak Load & Recovery \\
\hline \multirow{2}{*}{$\begin{array}{l}\text { Systolic blood pressure, } \\
\mathrm{mm} \mathrm{Hg}\end{array}$} & $\mathrm{I}$ & $118.6 \pm 11.7$ & $168.5 \pm 16.1 \# \# \#$ & $188.6 \pm 15.9$ \#\#\# & $122.2 \pm 12.2$ \\
\hline & Ii & $115.2 \pm 8.9 *$ & $163.9 \pm 13.2$ \#\# & 185.8 土 18.6 \#\#\# & $125.3 \pm 14.3$ \#\#\# \\
\hline \multirow{2}{*}{$\begin{array}{c}\text { Diastolic blood pressure, } \\
\mathrm{mm} \mathrm{Hg}\end{array}$} & $\mathrm{I}$ & $77.6 \pm 7.6$ & $70.6 \pm 13.9$ \#\#\# & 75.2 土 16.4 \#\#\# & 62.6 土 13.5 \#\#\# \\
\hline & $\mathrm{Ii}$ & $77.9 \pm 8.8$ & $77.1 \pm 11.5^{* *}$ & $83.4 \pm 14.7 *$ *\#\# & 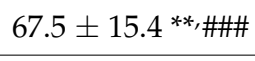 \\
\hline \multirow{2}{*}{$\begin{array}{l}\text { Heart rate, } \\
\text { beats } / \mathrm{min}\end{array}$} & $\mathrm{I}$ & $62.8 \pm 13.1$ & $166.3 \pm 13.3$ \#\#\# & $180.2 \pm 17.6$ \#\#\# & $108.2 \pm 13.3$ \#\#\# \\
\hline & Ii & $56.1 \pm 10.1^{* *}$ & $165.1 \pm 15.0$ \#\#\# & 177.8 土 17.3 \#\#\# & 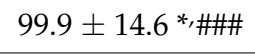 \\
\hline \multirow{2}{*}{$\begin{array}{l}\text { QRS complex, } \\
\text { ms }\end{array}$} & $\mathrm{I}$ & $103.8 \pm 8.9$ & $191.8 \pm 95.8 \# \# \#$ & $216.6 \pm 76.3 \#$ & $123.4 \pm 41.9$ \#\#\# \\
\hline & Ii & $106.4 \pm 8.9$ & $187.4 \pm 83.6$ \#\#\# & $213.3 \pm 87.3 \#$ & $113.6 \pm 19.7 \# \# \#$ \\
\hline \multirow{2}{*}{$\begin{array}{l}\text { QT interval, } \\
\text { ms }\end{array}$} & $\mathrm{I}$ & $394.2 \pm 24.9$ & $328.5 \pm 93.5 \# \# \#$ & $361.8 \pm 80.4 \#$ & $316.8 \pm 41.6$ \#\#\# \\
\hline & Ii & $412.5 \pm 29.4^{* * *}$ & $316.8 \pm 84.3 .1$ \#\#\# & $345.4 \pm 93.6 \#$ & $311.1 \pm 28.4$ \#\# \\
\hline \multirow{2}{*}{$\begin{array}{l}\text { Carbon dioxide production, } \\
\mathrm{L} / \mathrm{min}\end{array}$} & $\mathrm{I}$ & $0.3 \pm 0.1$ & $3.6 \pm 0.5 \# \# \#$ & $4.7 \pm 0.6 \# \# \#$ & $0.8 \pm 0.2 \# \# \#$ \\
\hline & Ii & $0.3 \pm 0.1$ & 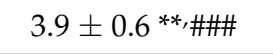 & $4.8 \pm 0.7$ \#\# & $0.8 \pm 0.2 \# \# \#$ \\
\hline \multirow{2}{*}{$\begin{array}{c}\text { Respiratory rate, } \\
\text { breaths per minute }\end{array}$} & $\mathrm{I}$ & $13.9 \pm 3.8$ & $35.6 \pm 8.2 \# \# \#$ & $50.2 \pm 10.1 \# \# \#$ & $25.8 \pm 5.8 \# \# \#$ \\
\hline & $\mathrm{Ii}$ & $13.6 \pm 3.9$ & $36.8 \pm 8.7$ \#\#\# & $50.8 \pm 12.4$ \#\#\# & $25.7 \pm 4.9$ \#\#\# \\
\hline
\end{tabular}

Statistical significance levels between groups: ${ }^{*} p<0.05 ;{ }^{* *} p<0.01 ;{ }^{* * *} p<0.001$ Statistical significance levels between stages of the load: \# $p<0.05$; \#\# $p<0.01$; \#\#\# $p<0.001$.

During the period of AT, at the peak load and at the recovery period, the DBP was significantly higher in the athletes of Group II than in the skiers of Group I $(p<0.01 ; p<0.05$ and $p<0.01$, respectively) (Table 2). The level of AT in Group I was decreased in DBP compared with the rest of the period $(p<0.01)$. Athletes in both groups showed an increase in DBP at the peak load compared with the AT Group $(p<0.001)$ and a decrease after five minutes of completion of the test $(p<0.001)$. There were no differences in DBP at rest or during the recovery period between the study groups $(p>0.05)$.

All cross-country skiers showed some similar dynamics of heart rate during the test "until exhaustion": an increase at the AT and at peak load and a decrease at recovery $(p<0.001)$ (Table 2). At rest and during the recovery period, Group I was characterized by a higher heart rate than Group II ( $p<0.01$ and $p<0.05$, respectively).

The dynamics of changes in the QRS complex in the two groups were similar; specifically, significant increases during the period of AT passage $(p<0.001)$ and at peak load $(p<0.05)$ and a decrease 5 minutes after the end of the test was noted $(p<0.001)$ (Table 2$)$. There were no significant differences in the QRS complexation during the test "until exhaustion" between the study groups $(p>0.05)$. A significant decrease in QT interval was found in both groups of cross-country skiers during the passage of the AT and at the recovery period $(p<0.001)$ and an increase at the peak of the load $(p<0.05)$. Significant differences in QT interval between groups were found only at rest $(p<0.001)$.

All cross-country skiers showed some similar dynamics of carbon dioxide production and respiratory rate during the test "until exhaustion": an increase at AT and at peak load and a decrease at recovery $(p<0.001)$. AT Group II was characterized by higher carbon dioxide production than Group I $(p<0.01)$.

\subsection{Biochemical Parameters}

At rest and during the test "until exhaustion", the values of $\mathrm{NO}_{\mathrm{x}}$ in Group II were significantly higher than the values of $\mathrm{NO}_{\mathrm{x}}$ in Group I $(p<0.01)$ (Figure 3). For athletes, 
Group I and Group II showed an increase in $\mathrm{NO}_{x}$ at the AT compared with the rest $(p<0.001$ and $p<0.05$, respectively) and a decrease for athletes in group II at peak load $(p<0.05)$. During the recovery period, the $\mathrm{NO}_{\mathrm{x}}$ level in the examined groups did not change compared to the peak load.

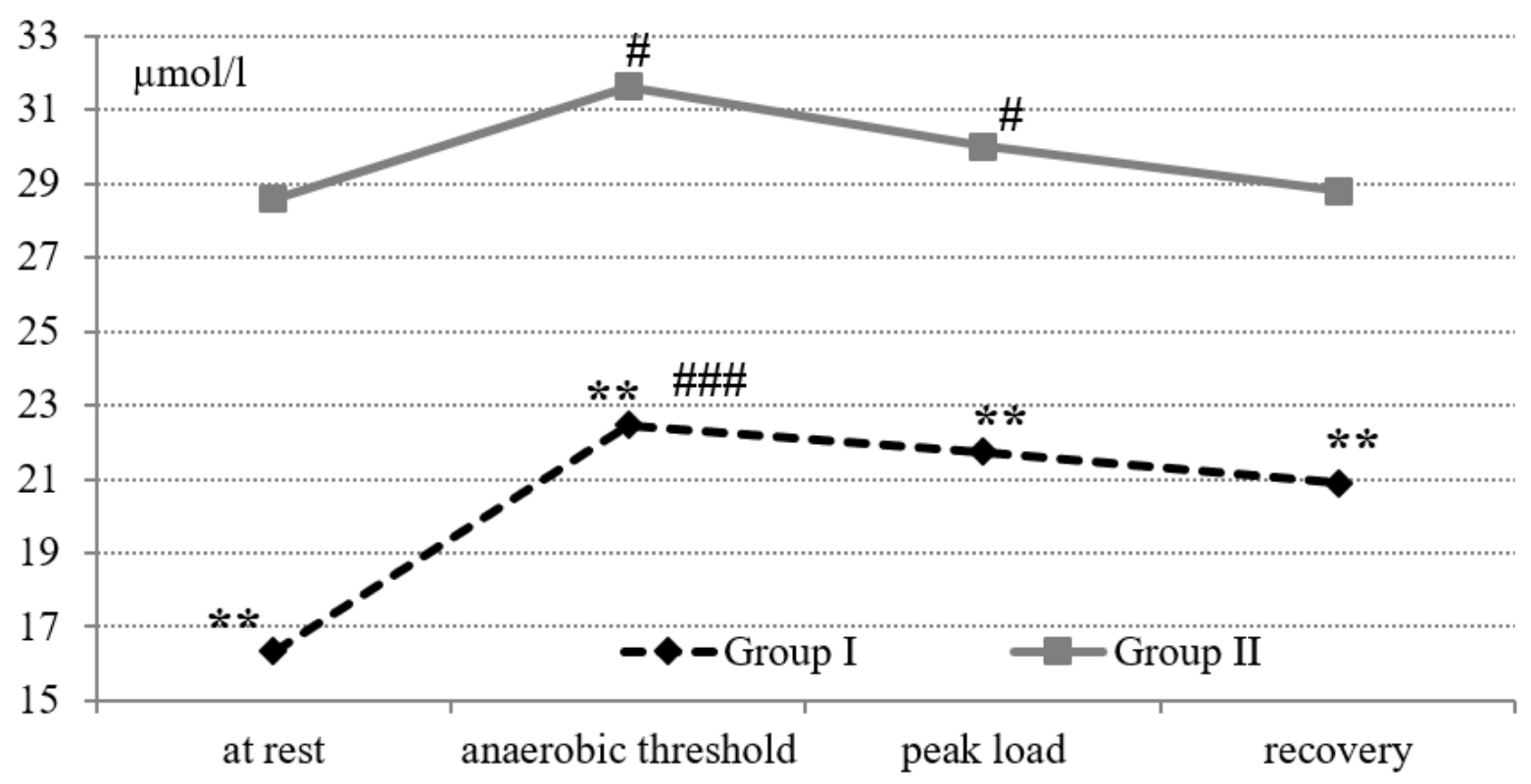

Figure 3. $\mathrm{NO}_{\mathrm{x}}$ level $(\mu \mathrm{mol} / \mathrm{L})$ during the exercise test on a cycle ergometer "until exhaustion" in cross-country skiers. Statistical significance levels between groups: ${ }^{* *} p<0.01$. Statistical significance levels between stages of the load: \# $p<0.05 ; \# \#$; $p<0.001$.

At rest, the $\mathrm{NO}_{2}$ value in Group II was significantly higher than the $\mathrm{NO}_{2}$ value in Group I ( $p<0.05$ ) (Table 3). The $\mathrm{NO}_{2}$ value between the studied groups of athletes at the AT, at peak load and at the recovery period did not show statistically significant changes $(p>0.05)$. A significant increase in the level of $\mathrm{NO}_{2}$ was detected only in Group I during the AT period compared with rest $(p<0.01)$. At rest and during the test "until exhaustion", the values of $\mathrm{NO}_{3}$ in Group II were significantly higher than the values of $\mathrm{NO}_{3}$ in Group I $(p<0.01)$. A statistically significant $(p<0.01-0.001)$ increase in $\mathrm{NO}_{3}$ was observed in all study groups during the passage of AT compared with the values at rest. In Group II, during the passage of the load peak, the $\mathrm{NO}_{3}$ value decreased significantly in comparison with the AT $(p<0.01)$. At the same time, in Group I, a statistically significant decrease in $\mathrm{NO}_{3}$ was observed during recovery compared to the peak load $(p<0.05)$.

Table 3. Nitric oxide and lactate levels at different stages of the load in cross-country skiers, ME \pm SD.

\begin{tabular}{|c|c|c|c|c|c|}
\hline \multirow{2}{*}{\multicolumn{2}{|c|}{ Parameters }} & \multicolumn{4}{|c|}{ Stages of the Load } \\
\hline & & \multirow{3}{*}{$\begin{array}{c}\text { At Rest } \\
8.1 \pm 3.6 \\
11.6 \pm 5.2 \text { * }\end{array}$} & \multirow{3}{*}{$\begin{array}{c}\begin{array}{c}\text { Anaerobic } \\
\text { Threshold }\end{array} \\
10.2 \pm 4.9 \# \# \\
11.6 \pm 6.1\end{array}$} & \multirow{3}{*}{$\begin{array}{c}\text { Peak Load } \\
9.8 \pm 3.9 \\
11.1 \pm 5.4\end{array}$} & \multirow{3}{*}{$\begin{array}{l}\text { Recovery } \\
10.7 \pm 4.5 \\
11.5 \pm 5.7\end{array}$} \\
\hline & I & & & & \\
\hline $\mathrm{NO}_{2}, \mu \mathrm{mol} / \mathrm{L}$ & Ii & & & & \\
\hline \multirow{2}{*}{$\mathrm{NO}_{3}, \mu \mathrm{mol} / \mathrm{L}$} & I & $8.2 \pm 4.0$ & $12.3 \pm 6.9 \# \# \#$ & $11.9 \pm 6.2$ & $10.2 \pm 5.8 \#$ \\
\hline & Ii & $17.2 \pm 8.6^{* *}$ & $20.0 \pm 10.6^{* * \text {,\#\# }}$ & $18.9 \pm 11.3^{* * \# \#}$ & $17.3 \pm 10.5^{* *}$ \\
\hline \multirow{2}{*}{$\mathrm{NO}_{3} / \mathrm{NO}_{2}$ index } & I & $1.5 \pm 0.5$ & $1.6 \pm 0.9$ & $1.6 \pm 0.2$ & $1.3 \pm 0.8$ \\
\hline & Ii & $2.3 \pm 0.6^{*}$ & $2.2 \pm 0.6^{*}$ & $2.2 \pm 1.3 *$ & $1.9 \pm 0.5^{*}$ \\
\hline \multirow{2}{*}{ Lactate, $\mu \mathrm{mol} / \mathrm{L}$} & I & $2.9 \pm 0.9$ & $6.2 \pm 1.6$ \#\#\# & $9.6 \pm 2.2 \# \# \#$ & $9.7 \pm 2.3$ \\
\hline & Ii & $2.0 \pm 0.8^{* *}$ & $6.4 \pm 1.8$ \#\#\# & $10.3 \pm 1.8$ \#\#\# & $9.8 \pm 2.7$ \\
\hline
\end{tabular}

Statistical significance levels between groups: ${ }^{*} p<0.05 ;{ }^{* *} p<0.01$ Statistical significance levels between stages of the load: \# $p<0.05$; \#\# $p<0.01$; \#\#\# $p<0.001$. 
The subjects of both groups showed no changes in the dynamics of the $\mathrm{NO}_{3} / \mathrm{NO}_{2}$ index during the test "until exhaustion". At the same time, Group II was characterized by higher values of the $\mathrm{NO}_{3} / \mathrm{NO}_{2}$ index than Group I $(p<0.05)$.

In representatives of different sports qualifications, the level of lactate in the blood increased during the test, while it did not recover after $5 \mathrm{~min}$ of the end of the test $(p<0.001)$ (Table 3). At rest in Group I, the lactate value was higher than the lactate value in Group II $(p<0.01)$.

\subsection{Interrelationship of Cardiorespiratory Parameters and Biochemical Parameters}

Correlation analysis between biochemical and cardiorespiratory parameters at different stages of the cross-country skiers in Groups I and II are presented in Tables 4 and 5, respectively. After correlation analysis, skiers of Groups I and II at rest showed a negative relationship between the values of $\mathrm{NO}_{x}$ and lactate $(\mathrm{r}=-0.26, p<0.05 ; \mathrm{r}=-0.44, p<0.001$, respectively), and Group II had a negative relationship between the values of $\mathrm{NO}_{3}$ and lactate $(\mathrm{r}=-0.30, p<0.05)$ (Table 4). However, in Group II, the relationship between $\mathrm{NO}_{\mathrm{x}}$ and lactate during the AT period became positive $(\mathrm{r}=0.30, p<0.01)$, and during the peak load period, the relationship between $\mathrm{NO}_{\mathrm{x}}$ and lactate again became negative $(\mathrm{r}=-0.26$, $p<0.05)$. In Group I, during the period of the peak load, a positive relationship was found between lactate and $\mathrm{NO}_{2}(\mathrm{r}=0.39, p<0.01)$, and a negative relationship was found with the $\mathrm{NO}_{3} / \mathrm{NO}_{2}$ index $(\mathrm{r}=-0.35, p<0.01)$. During the recovery period, no correlations were found between nitric oxide and lactate in the examined groups. In general, during the AT period, most of the correlations between nitric oxide and cardiorespiratory parameters were found in Group II.

Table 4. Correlations between biochemical and cardiorespiratory parameters at different stages of cross-country skiers in Group I.

\begin{tabular}{|c|c|c|c|c|}
\hline \multirow{2}{*}{ Stages of the Load } & \multirow{2}{*}{ Parameters } & \multicolumn{3}{|c|}{ Spearman Rank Order Correlations } \\
\hline & & $\mathrm{NO}_{\mathbf{x}}$ & $\mathrm{NO}_{2}$ & $\mathrm{NO}_{3}$ \\
\hline \multirow{10}{*}{$\begin{array}{l}\text { Before load, } \\
\text { at rest }\end{array}$} & SBP & -0.32 * & & \\
\hline & DBP & & & \\
\hline & $\mathrm{HR}$ & & & \\
\hline & QRS & & & \\
\hline & QT & & & \\
\hline & Lactate & -0.26 * & & \\
\hline & $\mathrm{V}^{\prime} \mathrm{O}_{2}$ & & & \\
\hline & $\mathrm{V}^{\prime} \mathrm{O}_{2} \max$ & 0.30 * & & \\
\hline & $\mathrm{V}^{\prime} \mathrm{CO}_{2}$ & & & \\
\hline & Rer & & & \\
\hline \multirow{10}{*}{ Anaerobic threshold } & SBP & $-0.25 *$ & $-0.36^{* *}$ & \\
\hline & DBP & & & \\
\hline & $\mathrm{HR}$ & & & \\
\hline & QRS & & & \\
\hline & QT & & & \\
\hline & Lactate & & & \\
\hline & $\mathrm{V}^{\prime} \mathrm{O}_{2}$ & $0.36^{* *}$ & $0.28 *$ & \\
\hline & $\mathrm{V}^{\prime} \mathrm{O}_{2} \max$ & $0.29 *$ & & \\
\hline & $\mathrm{V}^{\prime} \mathrm{CO}_{2}$ & 0.34 ** & & \\
\hline & Rer & & & \\
\hline
\end{tabular}


Table 4. Cont.

\begin{tabular}{|c|c|c|c|c|}
\hline \multirow{2}{*}{ Stages of the Load } & \multirow{2}{*}{ Parameters } & \multicolumn{3}{|c|}{ Spearman Rank Order Correlations } \\
\hline & & $\mathrm{NO}_{\mathbf{x}}$ & $\mathrm{NO}_{2}$ & $\mathrm{NO}_{3}$ \\
\hline Peak load & $\begin{array}{c}\text { SBP } \\
\text { DBP } \\
\mathrm{HR} \\
\mathrm{QRS} \\
\mathrm{QT} \\
\text { Lactate } \\
\mathrm{V}^{\prime} \mathrm{O}_{2} \\
\mathrm{~V}^{\prime} \mathrm{O}_{2} \text { max } \\
\mathrm{V}^{\prime} \mathrm{CO}_{2} \\
\text { Rer }\end{array}$ & & $0.39 * *$ & \\
\hline Recovery & $\begin{array}{c}\text { SBP } \\
\text { DBP } \\
\mathrm{HR} \\
\mathrm{QRS} \\
\mathrm{QT} \\
\text { Lactate } \\
\mathrm{V}^{\prime} \mathrm{O}_{2} \\
\mathrm{~V}^{\prime} \mathrm{O}_{2} \text { max } \\
\mathrm{V}^{\prime} \mathrm{CO}_{2} \\
\text { Rer }\end{array}$ & & & $0.29 *$ \\
\hline \multicolumn{5}{|c|}{$\begin{array}{l}\text { Statistical significance levels: }{ }^{*} p<0.05 ;{ }^{* *} p<0.01 \text {. SBP-systolic blood pressure, DBP-diastolic blood pressure } \\
\mathrm{HR} \text {-heart rate, QRS-QRS complex, QT-QT interval, } \mathrm{V}^{\prime} \mathrm{O}_{2} \text {-oxygen uptake, } \mathrm{V}^{\prime} \mathrm{O}_{2} \text { max-maximal oxygen uptake } \\
\mathrm{V}^{\prime} \mathrm{CO}_{2} \text {-carbon dioxide production, Rer-respiratory rate. } \\
\text { Table 5. Correlations between biochemical and cardiorespiratory parameters at different stages o } \\
\text { cross-country skiers in Group II. }\end{array}$} \\
\hline \multirow{2}{*}{ Stages of the Load } & \multirow{2}{*}{ Parameters } & \multicolumn{3}{|c|}{ Spearman Rank Order Correlations } \\
\hline & & $\mathrm{NO}_{\mathbf{x}}$ & $\mathrm{NO}_{2}$ & $\mathrm{NO}_{3}$ \\
\hline $\begin{array}{l}\text { Before load, } \\
\text { at rest }\end{array}$ & $\begin{array}{c}\text { SBP } \\
\text { DBP } \\
\mathrm{HR} \\
\text { QRS } \\
\mathrm{QT} \\
\text { Lactate } \\
\mathrm{V}^{\prime} \mathrm{O}_{2} \\
\mathrm{~V}^{\prime} \mathrm{O}_{2} \text { max } \\
\mathrm{V}^{\prime} \mathrm{CO}_{2} \\
\text { Rer }\end{array}$ & $\begin{array}{l}0.37^{* *} \\
-0.44^{* * *} \\
-0.26^{*}\end{array}$ & & $\begin{array}{l}-0.30 * \\
-0.30 * * \\
-0.26 *\end{array}$ \\
\hline Anaerobic threshold & $\begin{array}{c}\text { SBP } \\
\text { DBP } \\
\mathrm{HR} \\
\mathrm{QRS} \\
\mathrm{QT} \\
\text { Lactate } \\
\mathrm{V}^{\prime} \mathrm{O}_{2} \\
\mathrm{~V}^{\prime} \mathrm{O}_{2} \text { max } \\
\mathrm{V}^{\prime} \mathrm{CO}_{2} \\
\text { Rer }\end{array}$ & $\begin{array}{l}0.30^{* *} \\
0.33^{* *} \\
0.26^{*} \\
0.26^{*}\end{array}$ & $0.26 *$ & $\begin{array}{c}0.26^{*} \\
0.43^{* * *}\end{array}$ \\
\hline
\end{tabular}


Table 5. Cont.

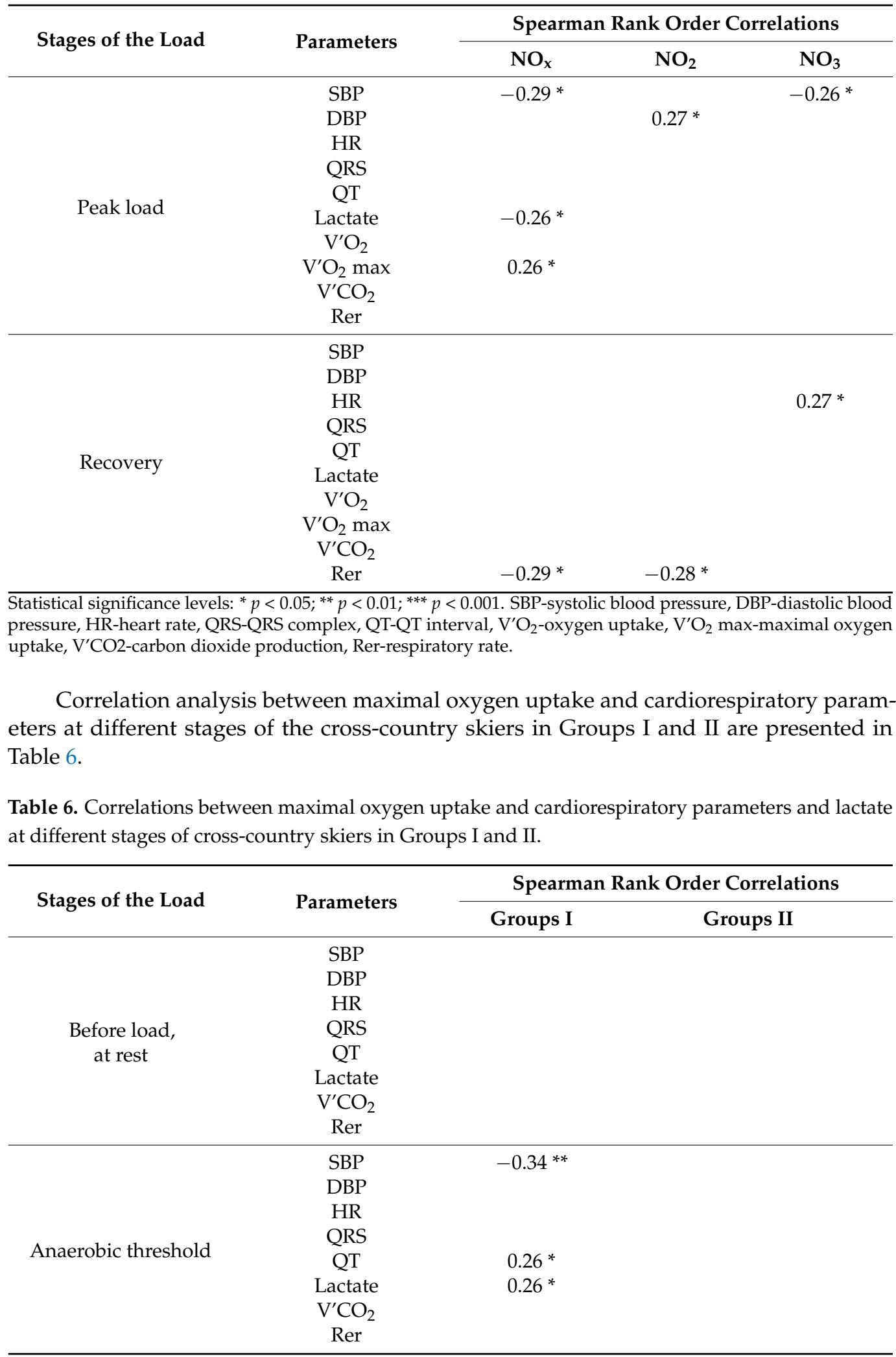


Table 6. Cont.

\begin{tabular}{ccc}
\hline \multirow{3}{*}{ Stages of the Load } & Parameters & \multicolumn{2}{c}{ Spearman Rank Order Correlations } \\
\cline { 2 - 3 } & Groups I & Groups II \\
\hline SBP & \\
DBP & \\
HR & \\
QRS & \\
QT & $0.33^{* *}$ \\
Lactate & \\
V'CO & \\
Rer & \\
Recovery & SBP & $-0.26^{*}$ \\
DBP & \\
HR & \\
QRS & \\
QT & \\
Lactate & \\
V'CO & \\
Rer & \\
\hline
\end{tabular}

Statistical significance levels: ${ }^{*} p<0.05 ;{ }^{* *} p<0.01$. SBP-systolic blood pressure, DBP-diastolic blood pressure, HR-heart rate, QRS-QRS complex, QT-QT interval, V'CO $\mathrm{CO}_{2}$-carbon dioxide production, Rer-respiratory rate.

During the AT, the peak load and during the recovery period showed a positive relationship between the maximal oxygen uptake and lactate in Group I $(\mathrm{r}=0.26, p<0.05$, $\mathrm{r}=0.33, p<0.01, \mathrm{r}=0.33, p<0.01$, respectively). In Group II, no correlations were found between maximal oxygen uptake and cardiorespiratory parameters.

\section{Discussion}

The main goal of our study was to identify the features of metabolic regulation in highly trained cross-country skiers of different qualifications at different stages of testing at physical maximum load. The study showed that elite athletes with higher results at official competitions were characterized by a higher anaerobic threshold and maximal oxygen uptake. Compared to the group, the athlete was not elite, which is comparable to the literature data $[11,12]$.

Cross-country skiers are known to have a very high maximal oxygen uptake and have equally trained upper and lower body muscles [4]. Thus, they are able to perform submaximal exercise at a rather high metabolic rate and with cardiac output levels similar to or higher than the cardiac output levels achieved by untrained humans at maximal exercise. Thus, this group of athletes is a successful model for studying metabolic effects in humans during intense physical work, especially since trained skiers can actually perform this intensive work, revealing subtle regulatory mechanisms. For example, elite Swedish skiers had a maximum oxygen uptake of $5.1 \pm 0.3 \mathrm{~L} / \mathrm{min}$ [13], which is $7.8 \%$ more than among the Group II skiers we examined. Our data on the maximum oxygen uptake also differ significantly in elite athletes from $\mathrm{V}^{\prime} \mathrm{O}_{2}$ max of Norwegian representatives of worldclass winter sports $[14,15]$, which are characterized by a maximum $\mathrm{V}^{\prime} \mathrm{O}_{2} / \mathrm{kg}$ from 80 to $90 \mathrm{~mL} / \mathrm{min} / \mathrm{kg}$ or $6.5 \mathrm{~L} / \mathrm{min}$, which is higher than in Group II surveyed by us by $27.6 \%$. Most likely, this difference can be explained by different methodological approaches for determining the $\mathrm{V}^{\prime} \mathrm{O}_{2}$ max and higher anthropometric indicators of elite Swedish skiers (height $180 \pm 2 \mathrm{~cm}$, weight $74 \pm 2 \mathrm{~kg}$ ) [13] and Norwegian representatives of world-class winter sports $[14,15]$.

The physical efficiency of athletes and the state of their cardiorespiratory system play leading roles among cross-country skiers in achieving high sports results. Physical aerobic exercise influences vascular remodelling, promoting angiogenesis, positively affecting the number of capillaries and therefore the gas exchange area, while improving oxygen diffusion and increasing vagus tone [14]. In the athletes examined in our study, SBP at rest 
corresponded to the norm [16]. At the same time, in Group I at rest, the SBP was statistically higher $(p<0.05)$ than in Group II, but during the exercise test, significant differences in SBP between the groups disappeared. A higher SBP in skiers of the 1st group, compared with Group II, could be associated with the incompleteness of the processes of the formation of the cardiovascular system against the background of significant sports loads.

At rest, DBP in all groups of cross-country skiers was above the norm, in comparison with the data obtained from students from a physical education department $(64.0 \pm 4.7 \mathrm{~mm} \mathrm{Hg})[16]$. It is known that prolonged training in open cold air can lead to an increase in peripheral vascular resistance and, as a consequence, to an increase in DBP [17]. Short-term (one-hour) cold exposure induces hypercoagulation in young healthy people, which can also cause a higher level of DBP [18]. According to the literature [19], cold air can indirectly lead to an increase in cardiovascular risks through its effect on the sympathetic and renin-angiotensin systems, blood pressure, and risk factors for atherosclerosis, such as blood viscosity, the amount of fibrinogen, lipids and uric acid. In our study, during the period of AT, at the peak load and at the recovery period, the DBP was significantly higher in the athletes of Group II than in the skiers of Group I $(p<0.01 ; p<0.05$ and $p<0.01$, respectively) (Table 2).

According to our data, the heart rate at rest in the skiers of Group I was 10.7\% higher than the heart rate at rest in Group II $(p<0.01)$, which indicates the formation of bradycardia as a result of sports training, which was more pronounced with an increase in sports activity. This assumption is confirmed by the higher values of the QT interval at rest in Group II compared with Group I. Aerobic exercise [20] affects the parasympathetic nerve, reducing the heart rate, which has a positive effect on reducing cardiovascular diseases. With an increase in sportsmanship, lower heart rate values may indicate [3] higher functional reserves.

On the one side, it was shown that low intensity exercise could improve antioxidant defences and lower lipid peroxidation levels [21]. On the other side, it is known that in the body of professional athletes under intense and strenuous physical exertion, oxidative stress [22] can occur, leading to the accumulation of lipid peroxidation products, including free radicals. Oxidative stress is the main reason for the decrease in the activity of NO synthase (NOS) through a decrease in the availability of the cofactor NOS-tetrahydrobiopterin and, subsequently, the inhibition of the enzymatic synthesis of NO. In our study, lower values of the $\mathrm{NO}_{\mathrm{x}}$ level during the test "to exhaustion" were observed in Group I skiers compared with athletes in Group II, which may indicate a decrease in the enzymatic synthesis of NO in athletes of Group I. The adaptive capacity of the body reduction with a decrease in the level of NO in the tissues, and pathological changes in metabolism are observed, leading to diseases. The primary cause of the pathogenesis of coronary heart disease and atherosclerotic vascular damage is a deficiency of NO in the vascular endothelium and myocardium [23]. There are several factors causing endothelial NO deficiency: a decrease in eNOS activity [24], destruction or capture of NO by free radicals, and/or a weakening of the effect of NO on smooth muscle [25].

In general, oxidative stress and hypoxia are believed to cause overproduction of $\mathrm{NO}$, often exceeding its physiological level [26,27]. In the body under oxidative stress, NO processes take place; for example, NO covalently binds to a cysteine residue in the beta-chain of $\mathrm{Hb}$ to form S-nitrosohaemoglobin, as well as other proteins, which has a regulatory effect on the local tissue blood supply during hypoxic vasodilation [28]. With gradual adaptation to oxidative stress (hypoxia), the plasma level of stable NO metabolites-nitrates and nitrites-progressively increases, correlating with an increase in the vascular NO depot [29]. Perhaps this mechanism of adaptation to the gradually increasing hypoxia caused by physical exertion of maximum power was observed in the elite athletes we examined.

Physiological effects [30] aimed at improving oxygen supply during hypoxia are well documented and include increased ventilation and cardiac output, erythropoiesis, and tissue vascularization [31]. Since $\mathrm{V}^{\prime} \mathrm{O}_{2}$ is determined by the interaction of several 
factors-blood flow, blood $\mathrm{O}_{2}$ carrying capacity, diffusion of $\mathrm{O}_{2}$ from blood to tissues, ATP demands and $\mathrm{O}_{2}$ utilization by mitochondria-it is clear that the result of changes in NO production on $\mathrm{V}^{\prime} \mathrm{O}_{2}$ depends on the balance between often opposite effects at different levels of the phenomena occurring.

Lactate levels in blood and tissues are assumed to increase during hypoxia. After $8 \mathrm{~h}$ of breathing in a chamber with hypoxic conditions of $12 \% \mathrm{O}_{2}$, a moderate increase in lactate levels of $29 \%$ was observed [32]. In our study, athletes of different sports classifications showed an increase in the level of lactate in the blood during the period of maximum exercise. Compared with the indices at rest in Group I, lactate increased by 3.3 times, and in Group II by 5.2 times ( $p<0.001$ ); therefore, the athletes examined by us experienced hypoxia during physical activity. Moreover, in Group II, hypoxia had a more pronounced character and a higher increase in $\mathrm{V}^{\prime} \mathrm{O}_{2}$ during the period of maximum load. As shown earlier, including our own study, fluctuations in the level of $\mathrm{NO}$ in the human body trigger various adaptive reactions under conditions of acute hypoxia [33,34].

Our data indicate that the baseline lactate level before the test "until exhaustion" is also significant, and this indicator is negatively correlated with the $\mathrm{NO}_{\mathrm{x}}$ indicator. In the literature, in some clinical conditions, there is a negative correlation between lactate and $\mathrm{NO}$; for example, in acute brain injury [35] and in major surgical operations [36], although with septic shock, the use of L-NMMA, an iNOS inhibitor, increases the level of lactate in the thigh muscle [37]. NO is a mediator of skeletal muscle function, especially NO, which affects cellular respiration and contractility, and in working skeletal muscle, inhibition of NOS improves the economy of muscle contraction and leads to a decrease in the outflow of lactate from the muscles by reducing oxygen cost [38].

Thiol reactions or reactive metal centres in proteins can cause NO responses for further biological events in skeletal muscle. The NO-mediated response inhibits haeme-containing proteins such as cytochrome c oxidase, thus inhibiting the function of cytochrome c oxidase and cell respiration [39]. Cytochrome c oxidase and the sarcoplasmic reticulum Ca21ATPase in fast-twitch and slow-twitch skeletal muscle inhibits by NOS activity which in turn leads to inhibiting mitochondrial respiration in skeletal muscle [40]. Moreover, aconitase and complex I of the respiratory chain can be additional targets of NO [41]. $\mathrm{NO}$ is crucial for the activation and inhibition of ryanodine receptors (RyRs) [42]. For muscle contraction and excitation, the release of $\mathrm{Ca}^{2+}$ into the cytosol is necessary, the RyR play a decisive role in this process. In recent years, special properties of $\mathrm{NO}_{2}$ have been shown, which make it possible to recognize it as the most significant biologically active signalling molecule [43]. The significant vasodilatory response observed in vivo and in vitro experiments upon administration of $\mathrm{NO}_{2}$ solutions suggests that it can be an alternative source of $\mathrm{NO}$ [44]. $\mathrm{NO}_{2}$ was also reported to participate in adaptation to physiological conditions of hypoxia, for example, caused by physical exertion [45]. Modern concepts of nitrite-dependent mechanisms of adaptation to hypoxia are based on data on the participation of $\mathrm{NO}_{2}$ in oxygen-dependent and hypoxia-dependent nitrite reductase processes. NO released as a result of these processes is involved in the regulation of vascular tone, modulation of mitochondrial redox reactions [46], changes in the sensitivity of heart contractile proteins to oxygen [47] and calcium ions [48], and inhibition of induced NOS. Due to the cyclic metabolic transformations of $\mathrm{NO}, \mathrm{NO}_{2}$ and $\mathrm{NO}_{3}$, the optimal level of $\mathrm{NO}$ is maintained, which is necessary for the normal functioning of the cardiovascular system in conditions of impaired functioning of NO synthases. However, excess NO is removed by the formation of an $\mathrm{NO}$ depot in the form of $\mathrm{NO}_{2}$, which protects tissues from oxidative and nitrosative stress. The source of vasoactive NO has now been established to also be $\mathrm{NO}_{2}$. It is always present in the blood and can be enzymatically reduced to $\mathrm{NO}$ under the action of xanthine oxidoreductase and nonenzymatic under conditions of low pH and pO2 [49]. Nitrate is reduced to nitrite and nitric oxide, which activate soluble guanylate cyclase [50]. Exercise has been shown to increase plasma nitrite levels by increasing NO synthesis in endothelial cells [51,52]. Plasma nitrite is oxidized to nitrate. This process is significantly accelerated by the presence of haeme proteins [53]. Nitrates are 
stable in plasma until excreted in the urine. The circulation of nitrite, rather than nitrate, indicates endothelial-dependent synthesis of NO [54]. Increased NO production during exercise is likely controlled by increased nitrate excretion as a possible mechanism for controlling plasma homeostasis [55]. When oxygen pressure decreases, nitrite reduction by deoxyhaemoglobin produces NO. The generation and release of NO by erythrocytes, along with the oxygen concentration gradient, can be associated with the role of nitrite bound to erythrocytes in the processes of vasodilation in response to hypoxia.

The indicators of correlation between the studied indices are of particular interest for discussion. Notably, there was a positive relationship between the parameters of $\mathrm{V}^{\prime} \mathrm{O} 2 \mathrm{max}$ and lactate in Group 1 at all stages of testing. However, in Group II, correlations between these indicators were not revealed at all.

It is also necessary to consider the correlation relationship between indicators of metabolites of nitric oxide and lactate during testing. Initially, at rest, $\mathrm{NO}_{\mathrm{x}}$ and lactate in both groups showed a significant negative correlation. In Group I, at the AT, correlation disappeared, and at the maximum load, the correlation was revealed between $\mathrm{NO}_{2}$ and lactate opposite direction. In Group II, at the AT, there was a positive relationship between $\mathrm{NO}_{\mathrm{x}}$ and lactate indicators, which inverted at maximum load. Thus, among skiers of Group II, a positive correlation of $\mathrm{NO}$ and lactate indicators was detected at the AT, and in Group I, the positive correlation of $\mathrm{NO}_{2}$ and lactate indicators was detected only at the maximum load. This observation suggests the existence of an adaptive mechanism for regulating the level of lactate at the AT in highly skilled skiers. The methodology of the training process in cyclic sports is known to be based on the principle of increasing the aerobic performance of the body of athletes. The phenomenon identified by us, in our opinion, may be reflects the positive effect of NO on the production of lactate, which provides an increase in aerobic performance. At the same time, at maximum load, on the contrary, it is required to maximize the activity of glycolysis and, accordingly, the production of lactate. In our opinion, activation of the reroute pyruvate away from pyruvate dehydrogenase $(\mathrm{PDH})$ in an $\mathrm{NO}$-dependent mechanism may be a possible mechanism explaining what is happening at the testing stage of highly skilled skiers at the AT (thereby promoting glutamine-based anaplerosis). The capability of this process was established in a recently published post [56]. To a certain extent, this hypothesis can be evidenced by our materials presented in Table 6. At rest, there was no correlation between lactate and $\mathrm{V}^{\prime} \mathrm{O}_{2}$ max in either group. However, in Group I, during exercise, a positive correlation of $\mathrm{V}^{\prime} \mathrm{O}_{2}$ max and lactate indices was manifested, which increased during the test until the recovery period. In contrast, in Group II during the entire test, there was no significant correlation between $\mathrm{V}^{\prime} \mathrm{O}_{2}$ max and lactate. In our opinion, this lack of significant correlation indicates that the level of lactate in the blood of highly qualified skiers-racers, in contrast to less qualified athletes with submaximal and maximum physical activity, does not depend on the parameters of the $\mathrm{V}^{\prime} \mathrm{O}_{2}$ max. It is likely that these athletes have developed additional adaptive mechanisms for regulating the production of lactate, one of which may be the activation of pyruvate abstraction through pyruvate dehydrogenase under conditions of aerobic work.

\section{Conclusions}

The results of our research indicate that the studied groups of athletes with high but different levels of sports qualifications are a convenient model for studying the molecular mechanisms of adaptation to physical loads of maximum intensity. Athletes of higher qualifications reveal additional adaptive mechanisms of metabolic regulation, which is manifested in the independence of serum lactate indicators under conditions of submaximal and maximum power from $\mathrm{V}^{\prime} \mathrm{O}_{2}$ max, and they have an $\mathrm{NO}$-dependent mechanism for regulating lactate levels during aerobic exercise, including work at the AT. Limitation: 1 . The sample is small to suggest solid conclusions. However, our study included 124 highly trained cross-countries skiers, who, at the time of testing, were current members of the national team of the Komi Republic and Russia. All participants were exposed to hard 
screening for a number of indicators and were unified. 2. An "until exhaustion" assessment needs further investigation due to the low degree of inter-sample analysis. 3. NO is not the only protagonist to guide the metabolic pathways. In the literature, much attention is paid to studying the role of the participation of nitric oxide interaction during inflammatory in rats $[57,58]$. At the same time, in our paper, we tried to reveal the mechanisms of the participation of nitric oxide in the process of adaptation to regular, hard and intense physical activity of healthy highly qualified athletes, who have developed specific mechanisms of adaptation to these loads.

\begin{abstract}
Author Contributions: All authors participated in designing the experiment. O.I.P. participated in the experimental procedure, carried out the biochemical studies, performed the statistical analysis and drafted the manuscript; N.G.V. participated in the experimental procedure, involved in data collection, and drafted the manuscript; N.N.P. carried out the biochemical studies, helped to draft the manuscript; A.Y.L. helped the statistical analysis; E.R.B. oversaw the experimental procedures, provided coordination, helped with drafting of the manuscript. All authors have agree with the order of presentation of the authors. All authors have read and agreed to the published version of the manuscript.
\end{abstract}

Funding: The study was carried out at the expense of subsidies for the implementation of State Assignment No. GR 1021051201877-3-3.1.8.

Institutional Review Board Statement: The study was conducted in accordance with the Declaration of Helsinki, and approved by the Ethics Committee of Institute of Physiology of Komi Science Centre of the Ural Branch of the Russian Academy of Sciences (date of approval: 23.10.2013).

Informed Consent Statement: Informed consent was obtained from all subjects involved in the study.

Data Availability Statement: The data that were generated and/or analyzed during the current study are available from the corresponding author upon reasonable request.

Conflicts of Interest: The authors declare no conflict of interest.

\title{
References
}

1. Baumgartner, L.; Schulz, T.; Oberhoffer, R.; Weberruß, H. Influence of vigorous physical activity on structure and function of the cardiovascular system in young athletes-The MuCAYA-Study. Front. Cardiovasc. Med. 2019, 6, 148. [CrossRef] [PubMed]

2. Varro, A.; Baczko, I. Possible mechanisms of sudden cardiac death in top athletes: A basic cardiac electrophysiological point of view. Cardiovasc. Physiol. 2010, 460, 31-40. [CrossRef] [PubMed]

3. Turbasova, N.V.; Bulygin, A.S.; Revnivykh, I.Y.; Karpov, N.V.; Elifanov, A.V. Anxiety level and parameters of the cardiovascular system in athletes of various qualifications. Hum. Sport Med. 2019, 19, 14-19. [CrossRef]

4. Saltin, B.; Astrand, P.O. Maximal oxygen uptake in athletes. J. Appl. Physiol. 1967, 23, 353-358. [CrossRef]

5. Parshukova, O.I.; Varlamova, N.G.; Bojko, E.R. Nitric oxide production in professional skiers during physical activity at maximum load. Front. Cardiovasc. Med. Hypertens. 2020, 7, 1-8. [CrossRef] [PubMed]

6. Yol, Y.; Turgay, F.; Yigitturk, O.; Asıkovalı, S.; Durmaz, B. The effects of regular aerobic exercise training on blood nitric oxide levels and oxidized LDL and the role of eNOS intron 4a/b polymorphism. BBA Molec. Bas. Dis. 2020, 1866, 165913. [CrossRef] [PubMed]

7. Windhaber, J.; Steinbauer, M.; Holter, M.; Wieland, A.; Kogler, K.; Riedl, R.; Schober, P.; Castellani, C.; Singer, G.; Till, H. Bicycle spiroergometry: Comparison of standardized examination protocols for adolescents: Is it necessary to define own standard values for each protocol? Eur. J. Appl. Physiol. 2021, 121, 1783-1794. [CrossRef]

8. Dickstein, K.; Barvik, S.; Aarsland, T.; Snapinn, S.; Karlsson, J. A comparison of methodologies in detection of the anaerobic threshold. Circulation 1990, 81, 38-46. [PubMed]

9. Myers, J.; Ashley, E. Dangerous curves. A perspective on exercise, lactate, and the anaerobic threshold. Chest 1997, 111, 787-795. [CrossRef] [PubMed]

10. Granger, D.L.; Taintor, R.R.; Boockvar, K.S.; Hibbs, J.B., Jr. Measurement of nitrate and nitrite in biological samples using nitrate reductase and Griess reaction. Methods Enzymol. 1996, 268, 142-151. [CrossRef]

11. Lorenz, D.S.; Reiman, M.P.; Lehecka, B.J.; Naylor, A. What performance characteristics determine elite versus nonelite athletes in the same sport? Sports Health 2013, 5, 542-547. [CrossRef]

12. Mitic, P.; Nedeljkovic, J.; Bojanic, Z.; Francesko, M.; Milovanovic, I.; Bianco, A.; Drid, P. Differences in the psychological profiles of elite and non-elite athletes. Front. Psychol. 2021, 12, 635651. [CrossRef] [PubMed]

13. Calbet, J.A.L.; Jensen-Urstad, M.; Van Hall, G.; Holmberg, H.C.; Rosdahl, H.; Saltin, B. Maximal muscular vascular conductances during whole body upright exercise in humans. J. Physiology 2004, 558, 319-331. [CrossRef] 
14. Martin, S.A.; Hadmaș, R.M. Individual adaptation in cross-country skiing based on tracking during training conditions. Sports 2019, 7, 211. [CrossRef] [PubMed]

15. Sandbakk, O.; Holmberg, H.C. Physiological capacity and training routines of elite cross-country skiers: Approaching the per limits of human endurance. Int. J. Space Physiol. Perform. 2017, 1, 1003-1011. [CrossRef]

16. Gjovaag, T.; Hjelmeland, A.K.; Oygard, J.B.; Vikne, H.; Mirtaheri, P. Acute hemodynamic and cardiovascular responses following resistance exercise to voluntary exhaustion. Effects of different loadings and exercise durations. J. Sports Med. Phys. Fit. 2016, 56, 616-623. [PubMed]

17. Varlamova, N.G.; Zenchenko, T.A.; Boyko, E.R. Annual dynamics of blood pressure and me-Teosensitivity in women. Ther. Arch 2017, 12, 56. [CrossRef]

18. Mercer, J.B.; Osterud, B.; Tveita, T. The effect of short-term cold exposure on risk factors for cardiovascular diseases from China. Thromb. Res. 1999, 95, 93-104. [CrossRef]

19. Luo, B.; Zhang, S.; Ma, S.; Zhou, J.; Wang, B. Artificial cold air increases the cardiovascular risks in spontaneously hypertensive rats. Int. J. Environ. Res. Public Health 2012, 9, 3197-3208. [CrossRef] [PubMed]

20. Oh, D.; Hong, H.; Lee, B. The effects of strenuous exercises on resting heart rate, blood pressure, and maximal oxygen uptake. J. Exerc. Rehabil. 2016, 12, 42-46. [CrossRef]

21. de Sire, A.; Marotta, N.; Marinaro, C.; Curci, C.; Invernizzi, M.; Ammendolia, A. Role of physical exercise and nutraceuticals in modulating molecular pathways of osteoarthritis. Int. J. Mol. Sci. 2021, 22, 5722. [CrossRef] [PubMed]

22. Heitzer, T.; Krohn, K.; Albers, S.; Meinertz, T. Tetrahydrobiopterin improves endothelium-dependent vasodilation by increasing nitric oxide activity in patients with type II Diabetes mellitus. Diabetologia 2000, 43, 1435-3148. [CrossRef]

23. Besedina, A. NO-synthase activity in patients with coronary heart disease associated with hypertension of different age Groups J. Med. Biochem. 2016, 35, 43-49. [CrossRef]

24. Chou, T.C.; Yen, M.H.; Li, C.Y.; Ding, Y.A. Alterations of nitric oxide synthase expression with aging and hypertension in rats. Hypertension 1998, 31, 643-648. [CrossRef]

25. Kizub, I.V.; Kharchenko, O.I.; Kostiuk, O.S.; Ostapchenko, L.I.; Soloviev, A.I. Protein kinase C (PKC) involved in enhancement of alpha (1)-adrenoceptor-mediated responses of the main pulmonary artery in rats with diabetes mellitus. Regul. Mech. Biosyst. 2017, 8, 287-292. [CrossRef]

26. Node, K.; Kitakaze, M.; Kosaka, H.; Komamura, K.; Minamino, T.; Inoue, M.; Tada, M.; Hori, M.; Kamada, T. Increased release of NO during ischemia reduces myocardial contractility and improves metabolic dysfunction. Circulation 1996, 93, 356-364. [CrossRef] [PubMed]

27. Hampl, V.; Herget, J. Role of nitric oxide in the pathogenesis of chronic pulmonary hypertension. Physiol. Rev. 2000, 80, 1337-1372. [CrossRef]

28. Allen, B.W.; Stamler, J.S.; Piantadosi, C.A. Hemoglobin, nitric oxide and molecular mechanisms of hypoxic vasodilation. Trends Mol. Med. 2009, 15, 452-460. [CrossRef]

29. Malyshev, I.Y.; Zenina, T.A.; Golubeva, L.Y.; Saltykova, V.A.; Manukhina, E.B.; Mikoyan, V.D.; Kubrina, L.N.; Vanin, A.F. NO-dependent mechanisms of adaptation to hypoxia. Nitric Oxide 1999, 3, 105-113. [CrossRef]

30. Murray, A.J. Metabolic adaptation of skeletal muscle to high altitude hypoxia: How new technologies could resolve the controversies. Genome Med. 2009, 1, 117. [CrossRef]

31. Sutton, J.R.; Reeves, J.T.; Wagner, P.D.; Groves, B.M.; Cymerman, A.; Malconian, M.K.; Rock, P.B.; Young, P.M.; Walter, S.D.; Houston, C.S. Operation Everest II: Oxygen transport during exercise at extreme simulated altitude. J. Appl. Physiol. 1988, 64, 1309-1321. [CrossRef] [PubMed]

32. Van Patot, M.C.T.; Serkova, N.J.; Haschke, M.; Kominsky, D.J.; Roach, R.C.; Christians, U.; Henthorn, T.K.; Honigman, B. Enhanced leukocyte HIF-1alpha and HIF-1 DNA binding in humans after rapid ascent to 4300 m. Free Radic. Biol. Med. 2009, 46, 1551-1557. [CrossRef]

33. Boiko, E.R.; Burykh, E.A. Nitric oxide metabolites level in human serum in acute normobaric hypoxia. Rossiiskii Fiziologicheskii Zhurnal Imeni IM Sechenova 2012, 98, 147-154. [PubMed]

34. MacInnis, M.J.; Carter, E.A.; Donnelly, J.; Koehle, M.S. A meta-analysis of exhaled nitric oxide in acute normobaric hypoxia. Aerosp. Med. Hum. Perform. 2015, 86, 693-697. [CrossRef]

35. Carpenter, K.L.; Timofeev, I.; Al-Rawi, P.G.; Menon, D.K.; Pickard, J.D.; Hutchinson, P.J. Nitric oxide in acute brain injury: A pilot study of $\mathrm{NO}(\mathrm{x})$ concentrations in human brain microdialysates and their relationship with energy metabolism. Acta Neurochir. 2008, 102, 207-213. [CrossRef]

36. Fujioka, S.; Noguchi, T.; Watanabe, T.; Takatsuto, S.; Yoshida, S. Biosynthesis of brassinosteroids in cultured cells of Catharanthus roseus. Phytochemistry 2000, 53, 549-553. [CrossRef]

37. Levy, B.; Valtier, M.; De Chillou, C.; Bollaert, P.E.; Cane, D.; Mallie, J.P. Beneficial effects of L-canavanine, a selective inhibitor of inducible nitric oxide synthase, on lactate metabolism and muscle high energy phosphates during endotoxic shock in rats. Shock 1999, 11, 98-103. [CrossRef] [PubMed]

38. Krause, D.S.; Van Etten, R.A. Tyrosine kinases as targets for cancer therapy. N. Engl. J. Med. 2005, 353, 172-187. [CrossRef]

39. Borutaite, V.; Brown, G.C. Rapid reduction of nitric oxide by mitochondria, and reversible inhibition of mitochondrial respiration by nitric oxide. Biochem. J. 1996, 1, 295-299. [CrossRef] [PubMed] 
40. Klebl, B.M.; Ayoub, A.T.; Pette, D. Protein oxidation, tyrosine nitration, and inactivation of sarcoplasmic reticulum Ca21-ATPase in low-frequency stimulated rabbit muscle. FEBS Lett. 1998, 422, 381-384. [CrossRef]

41. Clementi, E.; Brown, G.C.; Feelisch, M.; Moncada, S. Persistent inhibition of cell respiration by nitric oxide: Crucial role of Snitrosylation of mitochondrial complex I and protective action of glutathione. Proc. Natl. Acad. Sci. USA 1998, 95, 7631-7636. [CrossRef]

42. Stamler, J.S.; Meissner, G. Physiology of nitric oxide in skeletal muscle. Physiol. Rev. 2001, 81, 209-237. [CrossRef]

43. Mazzone, M.; Carmeliet, P. Drug discovery: A lifeline for suffocating tissues. Nature 2008, 453, 1194-1195. [CrossRef]

44. Schulman, I.H.; Hare, J.M. Regulation cardiovascular processes by S-nitrosylation. Biochim. Biophys. Acta 2012, 1820, 752-762. [CrossRef]

45. Gladwin, M.; Shelhamer, J.; Schechter, A.; Pease-Fye, M.; Waclawei, M.; Panza, J.; Oguibene, F.; Cannon, R. Role of circulating nitrite and S-nitrosohemoglobin in the regulation of the regional blood floow in humans. Proc. Natl. Acad. Sci. USA 2000, 97, 11482-11486. [CrossRef]

46. Gladwin, M.T.; Kim-Shapiro, D.B. The functional nitrite reductase activity of the heme globins. Blood 2008, 112, 2636-2647. [CrossRef]

47. Khan, S.A.; Skaf, M.N.; Harrison, R.W.; Lee, K.; Minhas, K.M.; Kumor, A.; Fradley, M.; Shoukas, A.; Berkowitz, D.E.; Hare, J.M Nitric oxide regulation of myocardial contractility and calcium cycling. Circ. Res. 2003, 92, 1322-1329. [CrossRef]

48. Layland, J.; Li, J.; Shah, A.M. Role cyclic GMP-dependent protein kinase in the contractile response to exogenous nitric oxide in rat cardiac myocytes. J. Physiol. 2002, 540, 457-467. [CrossRef] [PubMed]

49. Godber, B.L.; Doel, J.J.; Sapkota, G.P.; Blake, D.R.; Stevens, C.R.; Eisenthal, R.; Harrison, R. Reduction of nitrite to nitric oxide catalyzed by xanthine oxidoreductase. J. Biol. Chem. 2000, 275, 7757-7763. [CrossRef] [PubMed]

50. Zebrowska, A.; Mizia-Stec, K.; Mizia, M.; Gąsiorb, Z.; Poprzęcki, S. Omega-3 fatty acids supplementation improves endothelial function and maximal oxygen uptake in endurance-trained athletes. Eur. J. Sport Sci. 2015, 15, 305-314. [CrossRef] [PubMed]

51. Wang, J.S.; Chow, S.E.; Chen, J.K. Strenuous, acute exercise a Vects reciprocal modulation of platelet and polymorphonuclear leukocyte activities under shear Xow in men. J. Thromb. Haemost. 2003, 1, 2031-2037. [CrossRef]

52. Delp, M.D.; Laughlin, M.H. Time course of enhanced endothelium mediated dilation in aorta of trained rats. Med. Sci. Sports Exerc. 1997, 29, 1454-1461. [CrossRef] [PubMed]

53. Allen, J.D.; Cobb, F.R.; Gow, A.J. Regional and whole-body markers of nitric oxide production following hyperemic stimuli. Free Radic. Biol. Med. 2005, 38, 1164-1169. [CrossRef]

54. Kleinbongard, P.; Dejam, A.; Lauer, T.; Rassaf, T.; Picker, S.A.O.; Scheeren, T.; Godecke, A.; Schrader, J.; Schulz, R.; Heusch, G.; et al Plasma nitrite resects constitutive nitric oxide synthase activity in mammals. Free Radic. Biol. Med. 2003, 35, 790-796. [CrossRef]

55. Bode-Boger, S.M.; Boger, R.H.; Schroder, E.P.; Frolich, J.C. Exercise increases systemic nitric oxide production in men. J. Cardiovasc. Risk 1994, 1, 173-178. [CrossRef] [PubMed]

56. Palmieri, E.M.; Gonzalez-Cotto, M.; Baseler, W.A.; Davies, L.C.; Ghesquière, B.; Maio, N.; Rice, C.M.; Rouault, T.A.; Cassel, T.; Higashi, R.M.; et al. Nitric oxide orchestrates metabolic rewiring in M1 macrophages by targeting aconitase 2 and pyruvate dehydrogenase. Nat. Commun. 2020, 4, 698. [CrossRef] [PubMed]

57. Ilari, S.; Dagostino, C.; Malafoglia, V.; Lauro, F.; Giancotti, L.A.; Spila, A.; Proietti, S.; Ventrice, D.; Rizzo, M.; Gliozzi, M.; et al Protective effect of antioxidants in nitric oxide/COX-2 interaction during inflammatory pain: The role of nitration. Antioxidants 2020, 9, 1284. [CrossRef] [PubMed]

58. Iorio, G.C.; Ammendolia, A.; Marotta, N.; Ricardi, U.; Sire, A. A bond between rheumatic diseases and cancer in the elderly: The interleukin-6 pathway. Int. J. Rheum. Dis. 2021, 24, 1317-1320. [CrossRef] 